\title{
Does foliar silicon application enhance the biomass yield of millet silage, and does it
}

\section{provide significant economic gains?}

A aplicação foliar de silício aumenta o rendimento de biomassa do milheto para silagem e promove ganhos diferenciais econômicos?

¿Una aplicação foliar de silício aumenta o rendimento de biomassa da silagem de milheto y proporciona ganhos econômicos significativos?

\author{
Rilner Alves Flores \\ ORCID: https://orcid.org/0000-0002-6484-7150 \\ Universidade Federal de Goiás, Brazil \\ E-mail: rilner@ufg.br \\ Marco Aurélio Pessoa-de-Souza \\ ORCID: https://orcid.org/0000-0002-1367-8510 \\ Universidade Federal de Goiás, Brazil \\ E-mail: mpessoa@ufg.br \\ Amanda Magalhães Bueno \\ ORCID: https://orcid.org/0000-0001-8830-1040 \\ Universidade Federal de Goiás, Brazil \\ E-mail: amanda.mabu@gmail.com \\ Aline Franciel de Andrade \\ ORCID: https://orcid.org/0000-0001-8231-553X \\ Universidade Federal de Goiás, Brazil \\ E-mail: alineandrade418@gmail.com \\ Jonas Pereira de Souza Junior \\ ORCID: https://orcid.org/0000-0002-3421-0706 \\ Universidade Estadual Paulista, Brazil \\ E-mail: jonas.psj@hotmail.com \\ Klaus de Oliveira Abdala \\ ORCID: https://orcid.org/0000-0002-6466-9905 \\ Universidade Federal de Goiás, Brazil \\ E-mail: agroklaus@ufg.br \\ Renato de Mello Prado \\ ORCID: https://orcid.org/0000-0003-1998-6343 \\ Universidade Estadual Paulista, Brazil \\ E-mail: rm.prado@unesp.br \\ Glenio Guimarães Santos \\ ORCID: https://orcid.org/0000-0001-9399-4478 \\ Universidade Federal de Goiás, Brazil \\ E-mail: gleniogm@ufg.br \\ Marcio Mesquita \\ ORCID: https://orcid.org/0000-0002-0271-9751 \\ Universidade Federal de Goiás, Brazil \\ E-mail: marcio.mesquita@ufg.br
}

\begin{abstract}
Millet is a grass that has been highlighted for silage production, especially for being a productive tropical plant, and undemanding concerning soil fertility. Silicon ( $\mathrm{Si}$ ) is an alternative low-cost solution to increase biomass production, and it has been noticed to be beneficial to plants, especially when there are stress conditions. So, we analyzed the effects of foliar silicon application to gas exchanges, dry biomass production, and economic efficiency. We used a completely randomized experimental design consisting of foliar application of the following five doses of $\mathrm{Si}$ : $0 ; 0.84 ; 1.68 ; 2.52$; and $3.36 \mathrm{~g} \mathrm{~L}^{-1}$ of $\mathrm{Si}$ as potassium and sodium silicate, with five replications. We measured the plant height, leaf area, $\mathrm{Si}$ contents and accumulation in the plants, gas exchanges (stomatal conductance, transpiration, and photosynthesis net), dry matter production, Si uptake and transport efficiency by plants and its economic efficiency. The Si content enhanced and accumulated in all parts of millet plants, reaching values between 2.5 and $3.3 \mathrm{~g} \mathrm{~L}^{-1}$. There were linear increases of approximately 9 and $27 \%$ in height and leaf area of millet plants to $3.36 \mathrm{~g} \mathrm{~L}^{-1}$ of Si. Stomatal conductance and transpiration reached maximum values representing an increase of 44.60 and $101.30 \%$, respectively. The concentration of $3.36 \mathrm{~g} \mathrm{~L}^{-1}$ of $\mathrm{Si}$ increased photosynthesis by $76 \%$ and shoot dry matter production by $15 \%$, when compared to the
\end{abstract}


control. Si application is economically viable. The operational costs of application are suppressed, reaching to about US $\$ 45.32 \mathrm{ha}^{-1}$ with the application of $2.52 \mathrm{~g} \mathrm{~L}^{-1}$ of Si.

Keywords: Pennisetum glaucum; Beneficial element; Nutritional efficiency; Nutritional management.

\section{Resumo}

O milheto é uma gramínea que tem se destacado na produção de silagem, principalmente por ser uma planta tropical, produtiva e pouco exigente em relação à fertilidade do solo. Uma solução de baixo custo para aumentar a produção de biomassa é a aplicação de silício ( $\mathrm{Si}$ ), que tem se mostrado benéfico para as plantas, principalmente quando submetidas a condições de estresse. Assim, analisamos os efeitos da aplicação foliar de silício nas trocas gasosas, na produção de biomassa seca e na eficiência econômica. $\mathrm{O}$ delineamento experimental foi inteiramente casualizado, consistindo na aplicação foliar de cinco doses de Si: 0; 0,84; 1,68; 2,52; e 3,36 $\mathrm{g} \mathrm{L}^{-1}$ de Si aplicado como silicato de potássio e sódio, com cinco repetições. Avaliamos altura da planta, área foliar, conteúdo e acúmulo de Si na planta, trocas gasosas (condutância estomática, transpiração e fotossíntese líquida), produção de matéria seca, eficiência de absorção e transporte de Si pelas plantas e sua eficiência econômica. O teor de $\mathrm{Si}$ aumentou e se acumulou em todas as partes das plantas de milheto, atingindo valores entre 2,5 e 3,3 $\mathrm{g} \mathrm{L}^{-1}$. Houve aumentos lineares de aproximadamente 9 e $27 \%$ na altura e área foliar das plantas de milheto com $3,36 \mathrm{~g} \mathrm{~L}^{-1} \mathrm{de} \mathrm{Si}$. A condutância estomática e a transpiração atingiram valores máximos representando um aumento de 44,60 e 101,30\%, respectivamente. A concentração de $3,36 \mathrm{~g} \mathrm{~L}^{-1}$ de Si aumentou a fotossíntese em $76 \%$ e a produção de matéria seca da parte aérea em $15 \%$, quando comparada ao controle. A aplicação de Si é viável economicamente quando os custos operacionais da aplicação são suprimidos, podendo atingir US \$ 45,32 ha ${ }^{-1}$ com a aplicação de $2,52 \mathrm{~g} \mathrm{~L}^{-1}$ de Si.

Palavras-chave: Pennisetum glaucum; Elemento benéfico; Eficiência nutricional; Manejo nutricional.

\section{Resumen}

El mijo es una gramínea que se ha destacado para la producción de ensilaje, especialmente por ser una planta tropical productiva y poco exigente en cuanto a la fertilidad del suelo. Una solución de bajo costo para aumentar la producción de biomasa es la aplicación de silicio ( $\mathrm{Si}$ ), que ha demostrado ser beneficiosa para las plantas, especialmente cuando se someten a condiciones de estrés. Por lo tanto, analizamos los efectos de la aplicación foliar de silicio en los intercambios de gases, la producción de biomasa seca y la eficiencia económica. Se utilizó un diseño experimental completamente al azar que consistió en la aplicación foliar de las siguientes cinco dosis de Si: 0;0,84; 1,68; 2,52; y 3,36 g L $\mathrm{L}^{-1}$ de $\mathrm{Si}$ aplicado como silicato de potasio y sodio, con cinco repeticiones. Se evaluó la altura de la planta, el área foliar, el contenido y la acumulación de Si en la planta, los intercambios de gases (conductancia estomática, transpiración y fotosíntesis neta), la producción de materia seca, la absorción y la eficiencia de transporte de Si por las plantas y su eficiencia económica. El contenido de Si aumentó y se acumuló en todas las partes de las plantas de mijo, alcanzando valores entre 2,5 y 3,3 $\mathrm{g} \mathrm{L}^{-1}$. Hubo incrementos lineales de aproximadamente 9 y $27 \%$ en altura y área foliar de plantas de mijo con 3,36 $\mathrm{g} \mathrm{L}^{-1}$ de Si. La conductancia estomática y la transpiración alcanzaron valores máximos que representan un aumento del 44,60 y 101,30\%, respectivamente. La concentración de 3,36 g L ${ }^{-1}$ de Si aumentó la fotosíntesis en un $76 \%$ y disparó la producción de materia seca en un 15\%, en comparación con el control. La aplicación de Si es

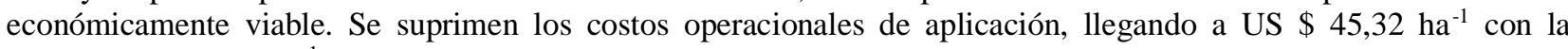
aplicación de $2,52 \mathrm{~g} \mathrm{~L}^{-1}$ de Si.

Palabras clave: Pennisetum glaucum; Elemento benéfico; Eficiencia nutricional; Manejo nutricional.

\section{Introduction}

Millet (Pannisetum glaucum) is a crop suitable for environments with low rainfall and water availability, high temperatures and soils with low fertility, being the main food and fodder source for agricultural communities in arid and semiarid tropics (Gupta et al., 2020). These characteristics are common in the Poaceae family and they are desirable for possible savings in crop production costs (Jukanti et al., 2016).

Another important feature is its ability to accumulate silicon ( $\mathrm{Si}$ ) (Epstein, 2009). Although studies on Si for this crop are incipient, its application has shown promising results, increasing yield when applied to Si-accumulating plants such as rice (Couto et al., 2020), sugarcane (Teixeira et al., 2020), maize (Oliveira et al., 2020a), sorghum (Flores et al., 2018a; Oliveira et al., 2020a), sunflower (Flores et al., 2018b; Peixoto et al., 2020), industrial processing tomato (Moraes et al., 2020), and wheat (Qamar et al., 2020).

Si can be supplied both through leaves and/or roots, being efficient to increase Si content and accumulation in the plant material, especially in Si-accumulating plants (Epstein, 2009). However, soil application requires high doses mainly due to the low solubility of silicates used (Lanna et al., 2016). Si sources with high solubility are alternatives, with foliar application being 
efficient to supply Si to grasses (Flores et al., 2018a; Couto et al., 2020; Teixeira et al., 2020), increasing Si uptake and transport efficiency in plants (Flores et al., 2018b), and increasing dry biomass production.

In this context, we believe that foliar application of a soluble Si source increases its contents and accumulation in millet plants, improving physiological quality, development, and biomass production with economic efficiency. Thus, we evaluated the effect of foliar silicon application on physiological quality, biomass production, and nutritional and economic efficiency of millet grown for silage.

\section{Methodology}

The study was conducted in a greenhouse at the School of Agronomy of the Goiás Federal University (UFG), Brazil, from February to October 2017. This experiment was done with a stand of 20 plants of millet (Pennisetum glaucum) variety ADR 500.

The initial chemical checkup of soil was made according Teixeira et al. (2017) and were presented the following attributes: pH: $4.4\left(\mathrm{CaCl}_{2}\right) ; \mathrm{Al}^{3+}: 0.5 \mathrm{cmol}_{\mathrm{c}} \mathrm{dm}^{-3}$; Soil Organic Material (SOM): $2.3 \mathrm{~g} \mathrm{dm}^{-3} ; \mathrm{P}: 0.8 \mathrm{mg} \mathrm{dm}^{-3} ; \mathrm{K}^{+}: 25 \mathrm{mg} \mathrm{dm}^{-3} ; \mathrm{Ca}^{2+}$ : $0.4 \mathrm{cmol}_{\mathrm{c}} \mathrm{dm}^{-3} ; \mathrm{Mg}^{2+}: 0.3 \mathrm{cmol}_{\mathrm{c}} \mathrm{dm}^{-3} ; \mathrm{SO}_{4}{ }^{2-}: 5.6 \mathrm{mg} \mathrm{dm}^{-3} ; \mathrm{Zn}^{2+}: 1.4 \mathrm{mg} \mathrm{dm}{ }^{-3} ; \mathrm{B}: 0.14 \mathrm{mg} \mathrm{dm}{ }^{-3} ;\left(\mathrm{H}+\mathrm{Al}^{3+}\right): 1.27 \mathrm{cmol}_{\mathrm{c}} \mathrm{dm}^{-3} ;$ Cation $^{-3}$ Exchange Capacity (CEC): $2.03 \mathrm{cmol}_{\mathrm{c}} \mathrm{dm}^{-3}$; Base Saturation (V\%): $37.4 \%$. The characterization of soil particle-size presented a proportion of 530.0, 180.0, and $135.0 \mathrm{~g} \mathrm{~kg}^{-1}$, a ratio of clay, silt, and sand, respectively.

Plants were grown in $10 \mathrm{~L}$ pots filled with local soil (RED LATOSOL) supplemented with dolomitic limestone (CaO $=36 \% ; \mathrm{MgO}=15 \% ; \mathrm{PN}=98 \% ; \mathrm{PRNT}=92.54 \%$ ), to maintain the soil moisture. Plants were watered daily and fertilized weekly with Souza \& Lobato (2004). Irrigation was made with deionized water, using the pot weighing method to keep humidity at $60 \%$ retention capacity. The greenhouse temperature during the plant growth and the experiment was around $32 \pm 3{ }^{\circ} \mathrm{C}$ during the day, and $26 \pm 3{ }^{\circ} \mathrm{C}$ during the night.

To prepare soil for planting, one of the steps were to add the basic fertilization protocol, based on the rates required by the culture which was $80 \mathrm{~kg} \mathrm{ha}^{-1}$ of $\mathrm{P}_{2} \mathrm{O}_{5}$, using monoammonium phosphate (MAP) as $\mathrm{P}$ source, $60 \mathrm{~kg} \mathrm{ha}^{-1}$ of $\mathrm{K}_{2} \mathrm{O}$ as potassium chloride $(\mathrm{KCl})$ and, $80 \mathrm{~kg} \mathrm{ha}^{-1}$ using urea as a source of $\mathrm{N}$, divided into two moments: $20 \mathrm{~kg} \mathrm{ha}^{-1}$ on soil preparation step and 60 $\mathrm{kg} \mathrm{ha}^{-1} 30$ days after planting, as reported by Souza \& Lobato (2004).

Plants were randomly separated into five groups of 4 plants each. Plants were assigned to receive Si application in five

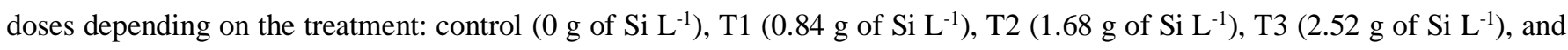
$\mathrm{T} 4$ (3.36 $\mathrm{g}_{\text {of } \mathrm{Si} \mathrm{L}^{-1}}$ ). Silicon was applied in the form of potassium and sodium silicate stabilized with sorbitol $\left(\mathrm{Si}=62.9 \% ; \mathrm{K}_{2} \mathrm{O}\right.$ $=21.3 \% ; \mathrm{Na}_{2} \mathrm{O}=15.7 \% ; \mathrm{d}=1.15 \mathrm{~g} \mathrm{~L}^{-1} ; \mathrm{pH}=12.0$; and soluble in water). In order to maintain the same potassium fertilization for all plants, each treatment received $\mathrm{KCl}$ fertilization at the following concentrations: control, 1.904; T1, 1.428; T2, 0.952; T3, 0.476 and, $\mathrm{T} 4,0 \mathrm{~g} \mathrm{~L}^{-1}$ of $\mathrm{KCl}$.

Leaf Si fertilization was divided into three applications: 1/3 of the vegetative state (at 15 days after plant emergence DAE), 2/3 of the vegetative state (30 DAE), and at the end of the vegetative state in pre-bloom (45 DAE). Silicon was applied on the leaves and was made using a sprinkler. Pots were covered with impermeable material before spraying to avoid contact with soil and cause any kind of overdose.

At 70 DAE, gas exchange measurements were performed using a LiCor 6400 (LiCor, Lincoln-NE), at $2000 \mu \mathrm{mol} \mathrm{m}^{-2}$ $\mathrm{s}^{-1}$ of illumination, ambient $\mathrm{CO}_{2}$ concentration $\left(400 \mu \mathrm{mol} \mathrm{mol}^{-1}\right)$, temperature of $32{ }^{\circ} \mathrm{C}$, and vapor pressure deficit of the leaf of 1.5-2.0 kPa. Gas exchange was performed in one leaf per plant, on the youngest fully expanded leaf of each plant. Right after gas exchange measurement, the leaves were counted, the area of each leaf was measured, and the plant was harvested. 
The forage grass was cut 70 days after plant emergence (DAE) and some phytotechnical measures were analyzed as height of the plants (starting from the base up until the insertion of the last leaf) and leaf area using a pachymeter (Model LI3100).

The samples were washed with a solution containing $0.1 \%$ detergent, $0.3 \%$ acidic solution and distilled water, to decontaminate possible residues from the foliar applications. The plant was then dried for $72 \mathrm{~h}$ at $60{ }^{\circ} \mathrm{C}$ and weighted for biomass yield. Dried leaf samples were taken for quantification of Si content. Silicon content was determined using the alkaline digestion method described by Korndörfer (2004). Then, the accumulation of Si in the aerial part was calculated using leaf tissue Si content data, as well as the increase in dry mass.

Using the dry matter and nutrients content in plants data were performed the calculation of nutritional indices comprising absorption efficiency $\left(\mathrm{AB}_{\mathrm{ef}}\right)$ and transport efficiency $\left(\mathrm{TR}_{\mathrm{ef}}\right)$ These calculations were proceeded as following:

Equation (Swiader et al., 1994):

$$
\mathrm{AB}_{\mathrm{ef}}=\frac{\text { total nutrient content in plant }}{\text { root dry matter }}
$$

Equation (Li et al., 1991):

$$
\mathrm{TR}_{\mathrm{ef}}=\frac{\text { nutrient content in aerial part }}{\text { total nutrient content in the plant }}
$$

For economic analysis, the partial budgeting method was used according to Noronha (1987). The method calculates the effects of additional costs and revenues in relation to a baseline, providing differential profits (Dp) as an economic indicator by using the following equation:

$$
\mathrm{Dp}=\mathrm{Dr}-\mathrm{Dc}
$$

Where:

$\mathrm{Dp}=$ Differential revenue, calculated from the variation of the yield obtained in each treatment in relation to the control, considered as baseline. In order to determine the pecuniary value of millet biomass, the current data available on the MFrural website (https://www.mfrural.com.br/) was used. The lowest value for one ton of sorghum silage was used as a reference, as there were no offers of millet silage. Freight value was added in order to obtain the value of the product on the farm. According to this approach, it was possible to obtain the price of US $\$ 48.55 \mathrm{t}^{-1}$ of millet on the farm.

Dc $=$ Differential cost, calculated from the price of the dose of the product used in each treatment, as they already differed from the control.

We highlight that analyses were performed in relation to the input price, resulting in the differential cost of the input and the cost of the dose added to the operational cost of application, resulting in the differential cost of operation. The operational cost of application was obtained from Román et al. (2019), who evaluated the operational efficiency of application for different spray volumes. This study allowed us to calculate the updated value (US \$ - 2020) of US $\$ 46.55$ for three applications at spray volume of $100 \mathrm{~L} \mathrm{ha}^{-1}$.

Thus, it was possible to calculate from Eq.1 the differential profit (Dp) for each treatment in relation to the control, which was subdivided into Dpi $=$ Differential profit of input and Dpo $=$ Differential profit of operation .

Finally, we compared the impact of the differential costs of input and application on the effective cost of operation of millet silage production. Such cost was obtained from Pompeu et al. (2013) and corrected to dollar values of 2020 (as of December 8,2020 , US $\$ 1=$ BR \$ 5.08), resulting in a value of US $\$ 901.13 \mathrm{ha}^{-1}$.

Once the data have been collected and inspected, they were analyzed statistically with analysis of variance (ANOVA), and after that, polynomial regression analysis. Data main effects were subjected to polynomial components in the overall response, and then regression methods were applied to the continuous variable to develop an equation that explains the significant 
trend in response (5\% probability by the $t$-test). Variable were correlated by the Pearson linear correlation test (Sigma-plot In., USA) considering the correlation significances ( $\mathrm{p} \leq 0.01$ and 0.05 ).

\section{Results}

Silicon application was responsive to height $(\mathrm{cm})$ (Figure 1 a) and leaf area $\left(\mathrm{cm}^{2}\right)$ (Figure $1 \mathrm{~b}$ ) with the concentration of $3.36 \mathrm{~g} \mathrm{~L}^{-1}$ of Si, obtaining maximum values and increasing approximately 9 and $27 \%$ in relation to the control treatment, respectively. Millet height significantly responded up to $82 \%$ of probability, and leaf area up to $93 \%$, demonstrating direct effect of Si application on plant volume.

Figure 1. Height $(\mathrm{cm})(\mathrm{a})$, leaf area $\left(\mathrm{cm}^{2}\right)(\mathrm{b})$ roots dry mass (g per plant) $(\mathrm{c})$ and shoot dry mass (g per plant) (d) under different Si concentration applied in leaves. $*$ and ${ }^{\text {ns }}$ - statistical significant and non-significant by F-test at $5 \%$ probability, respectively.
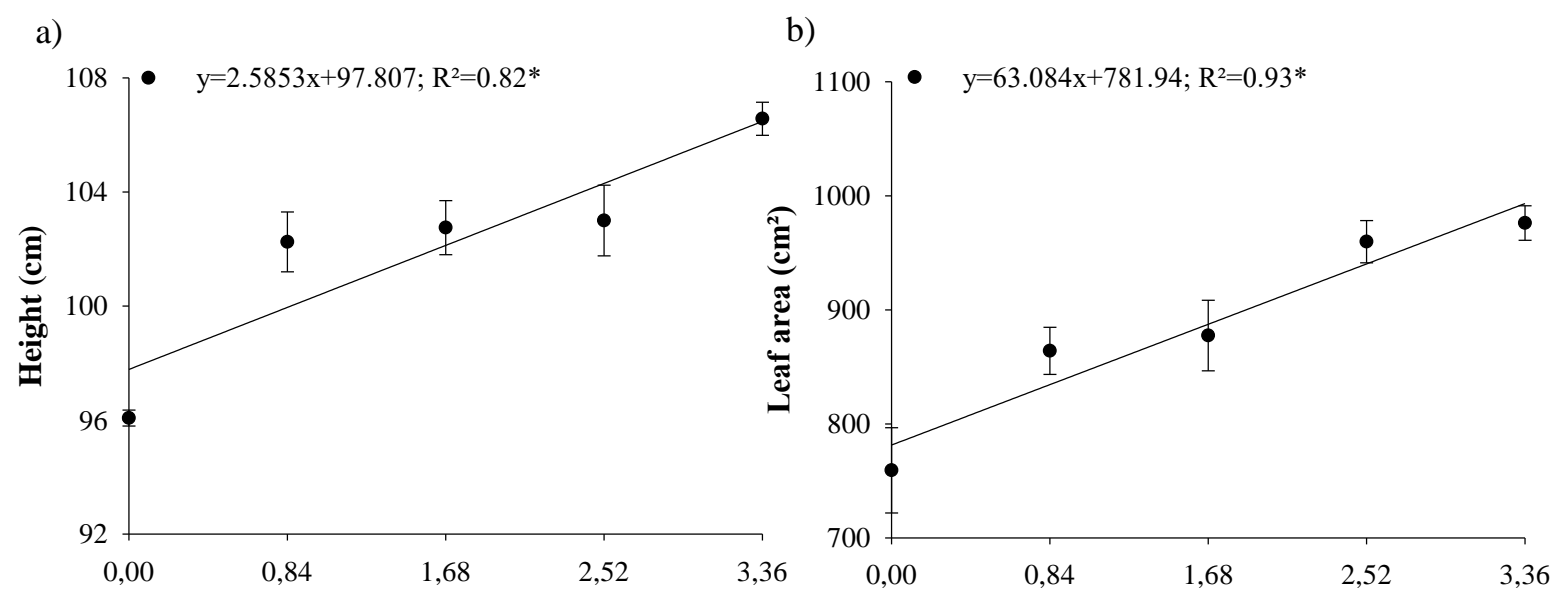

c)

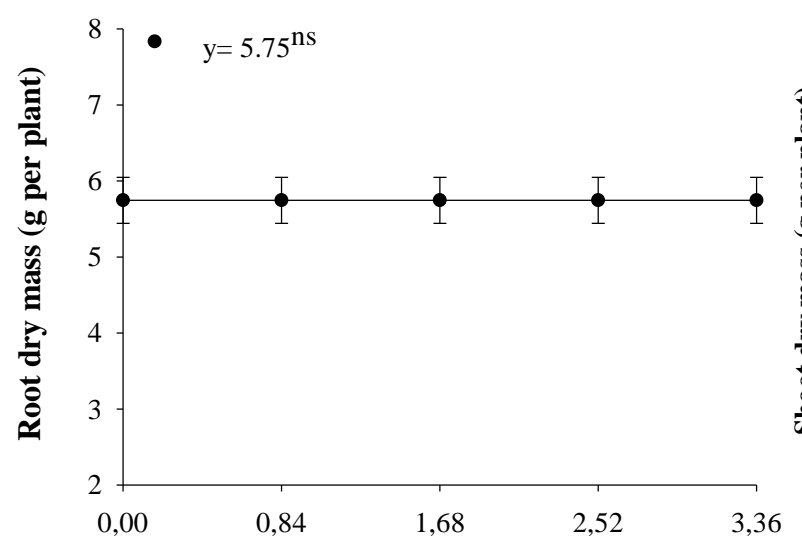

d)

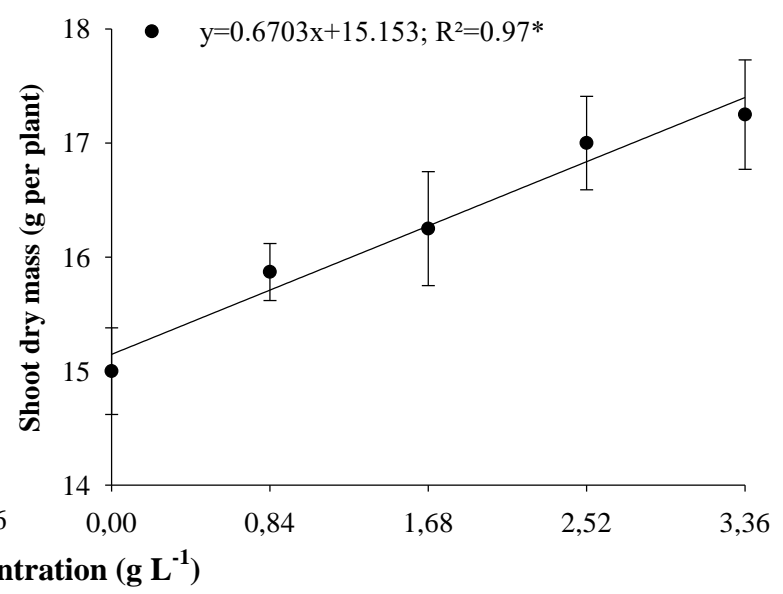

Source: Authors.

Roots are not responsible for millet biomass crop gains when Si was added to the system (Figure $1 \mathrm{c}$ ). Roots presented an average production of $5.75 \mathrm{~g}$ per plant. On the other hand, there was an increasing linear adjustment in shoot dry mass responses after Si spraying (Figure $1 \mathrm{~d}$ ). This relation reached $17.41 \mathrm{~g}$ per plant at $3.36 \mathrm{~g} \mathrm{~L}^{-1}$ of Si dose, near to $15 \%$ about the control treatment.

Physiological parameters also showed different responses to foliar silicon application (Figure 2). Stomatal conductance and transpiration behaved in quadratic equation among treatments with $88 \%$ and $77 \%$ probability data distribution according to the variation of doses of Si applied, respectively. These both data groups reached $8.73 \mathrm{mmol} \mathrm{m}^{-2} \mathrm{~s}^{-1}$ and $0.43 \mathrm{mmol} \mathrm{m}^{-2} \mathrm{~s}^{-1}$ as 
maximum levels to stomatal conductance and transpiration, respectively. These results can inform categorically that $2.52 \mathrm{~g} \mathrm{~L}^{-1}$ of $\mathrm{Si}$ is the maximum dose acceptable for millet crop production in subtropical systems. In contrast, net photosynthesis responded linearly to variations of the dose of $\mathrm{Si}$, with $99 \%$ probability, being more responsive to the highest dose of $\mathrm{Si}$ applied, $3.36 \mathrm{~g} \mathrm{~L}$ ${ }^{1}$. On this dose, the system reached $1.66 \mu \mathrm{mol} \mathrm{m}^{-2} \mathrm{~s}^{-1}$, around $76 \%$ being higher than the control treatment.

Figure 2. Stomatal conductance $\left(\mathrm{mmol} \mathrm{m}^{-2} \mathrm{~s}^{-1}\right)(\mathrm{a})$, Transpiration $\left(\mathrm{mmol} \mathrm{m} \mathrm{m}^{-2} \mathrm{~s}^{-1}\right)(\mathrm{b})$ and Liquid photosynthesis $\left(\mu \mathrm{mol} \mathrm{m}^{-2} \mathrm{~s}^{-1}\right)$ (c) of millet cultivated under different $\mathrm{Si}$ concentrations supplied by leaves. ${ }^{*}$ and ${ }^{* *}$ - statistical significant by F-test at $5 \%$ and $1 \%$ probability, respectively.

a)

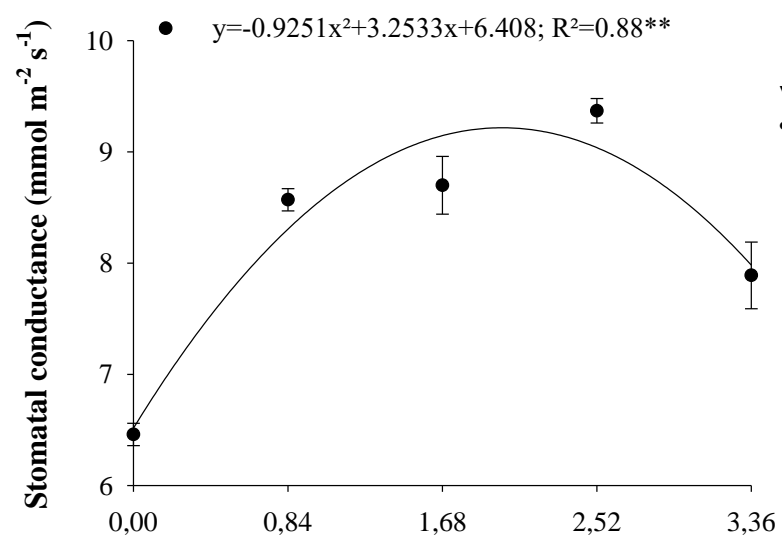

b)

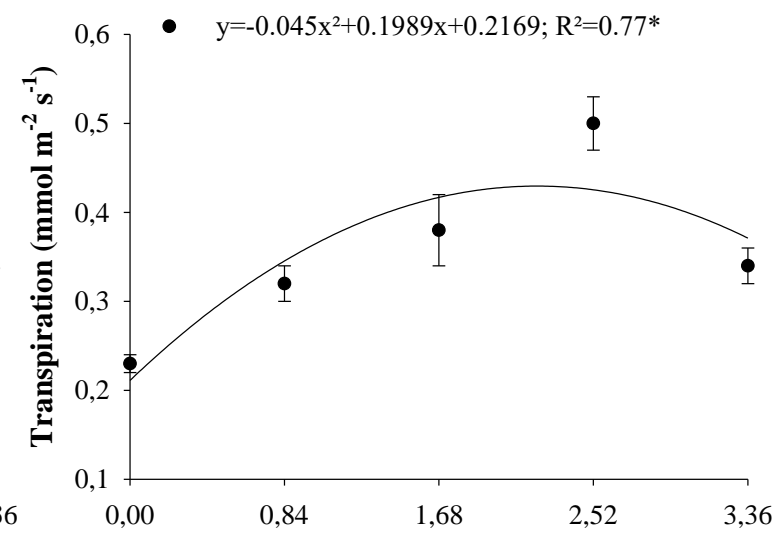

c)

Si concentration $\left(\mathrm{g} \mathrm{L}^{-1}\right)$

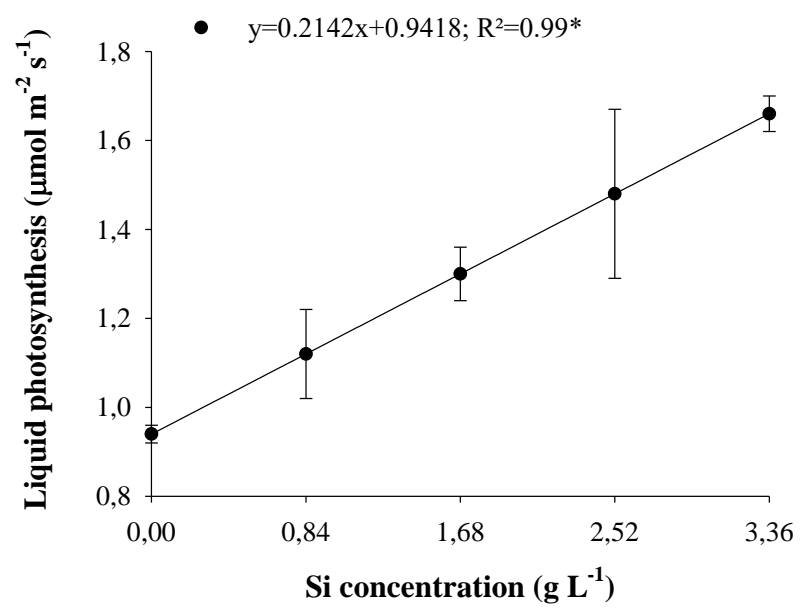

Source: Authors.

Si also boosted content (Figure 3 a) and accumulation (Figure 3 b) in plant tissues with Silicon dose variation. As higher as $\mathrm{Si}$ application in the systems, high also was the responses in foliar Si content and accumulation. Still, Figure 3a can demonstrate quadratic adjustment response when $\mathrm{Si}$ content is analyzed in the millet plants configuring values around $9.84 \mathrm{~g} \mathrm{~kg}$ ${ }^{1}$ and $15.42 \mathrm{~g} \mathrm{~kg}^{-1}$ with $2.47 \mathrm{~g} \mathrm{~L}^{-1}$ of $\mathrm{Si}$ by roots, and with $2.67 \mathrm{~g} \mathrm{~L}^{-1}$ of $\mathrm{Si}$ by leaf applications, respectively; these data are representing 38\% and 50\% higher than control treatment (Figure 3 a). In the same way, Si plant accumulation also increased as further as Si dose got near to $56.82 \mathrm{mg}$ per the root plants, and $288.21 \mathrm{~g}$ per the shoot plant. These results were observed in 2.39 and $3.27 \mathrm{~g} \mathrm{~L}^{-1}$ of $\mathrm{Si}$ doses, respectively (Figure $3 \mathrm{~b}$ ). 
Figure 3. Si content $\left(\mathrm{g} \mathrm{kg}^{-1}\right.$ ) (a) and $\mathrm{Si}$ accumulation (mg per plant) (b) in two conditions (roots and aerial part (AP)) of cultivated millet under different concentration of Si by foliar application. ${ }^{*}$ - statistical significant F-test at 5\% probability.
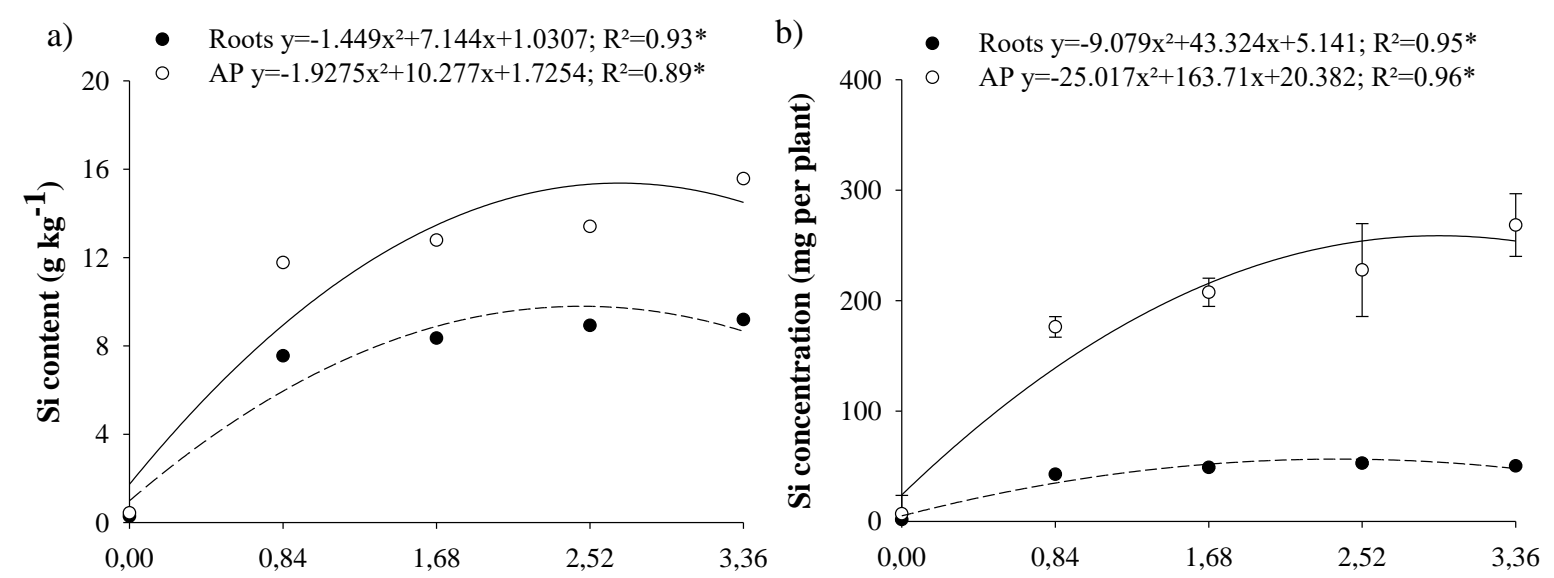

Si concentration $\left(\mathrm{g} \mathrm{L}^{-1}\right)$

Source: Authors.

Our results, when analyzed regarding absorption and transport efficiency (Figure 4), confirm all previous results. Not only Si content and concentration, but also the variation of this element in foliar application increased the uptake capacity of plants. Furthermore, they confirm the hypothesis that millet may be a Si-accumulating plant, as besides showing tolerance for absorption, millet also has a notable capacity of transporting $\mathrm{Si}$ to leaves as to improve photosynthetic efficiency, as previously reported (Figure 2). Yet, the increase and absorption of Si by the plant promote an exponential decrease of Si conversion rate into biomass. That phenomenon happens even with the natural capacity of high $\mathrm{Si}$ absorption and transport for millet demonstrating an opposite behavior because Si use is reduced the absorption capacity of this element by the plant (Figure $4 \mathrm{c}$ ).

When performing economic analysis through partial budgeting, we observed that differential profits are negative for all doses of Si applied, indicating that, according to the current prices of the products and inputs applied, the operation of application with three sprays is economically inefficient, regardless of the dose applied (Figure 5). However, when evaluating only the differential profits of the input, we observed positive result, proving it to be economically efficient, regardless of Si dose applied, when compared to the control treatment. Moreover, with application of $2.52 \mathrm{~g} \mathrm{~L}^{-1}$ of $\mathrm{Si}$ in spraying with $100 \mathrm{~L} \mathrm{ha}^{-1}$, we obtained the best differential profit of input, US $\$ 45.32 \mathrm{ha}^{-1}$. 
Figure 4. Absorption efficiency ( $\mathrm{mg} \mathrm{g}^{-1}$ ) (a), transport efficiency (\%) (b) and use efficiency (mg g-1) (c) of silicon by millet leaves under different concentration from millet leaves. * - statistical significant by F-test at 5\% probability.

a)

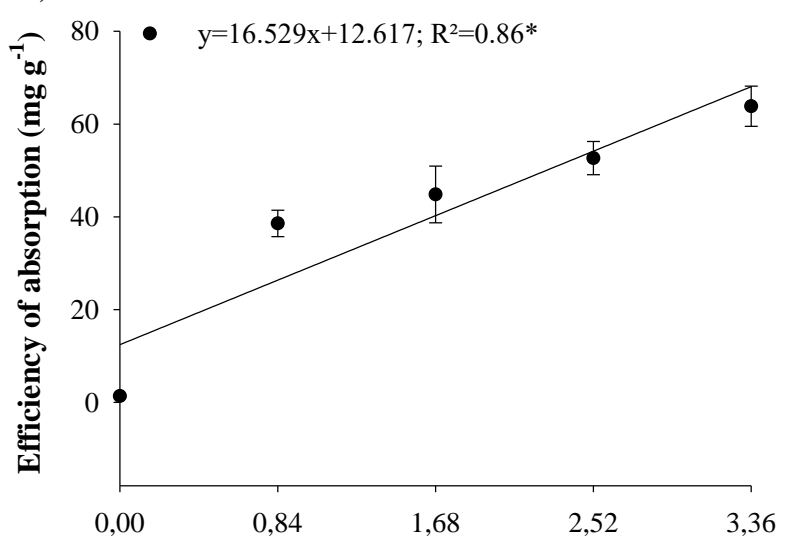

b)

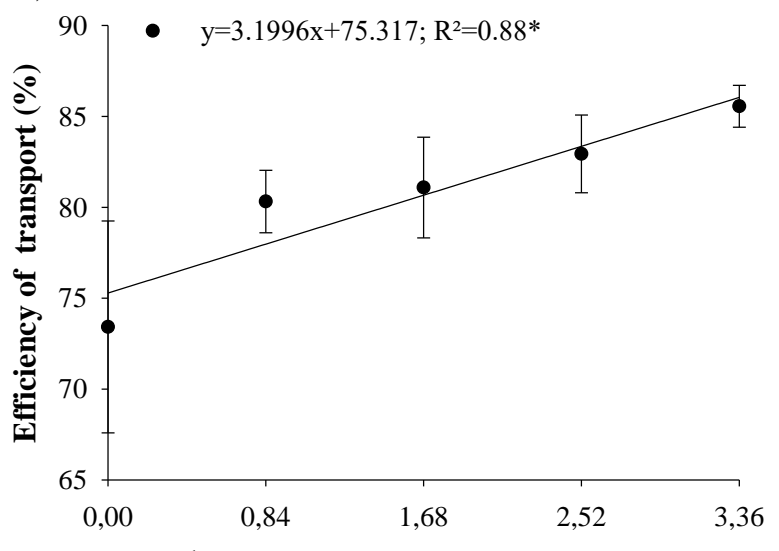

c)

Si concentration $\left(\mathrm{g} \mathrm{L}^{-1}\right)$

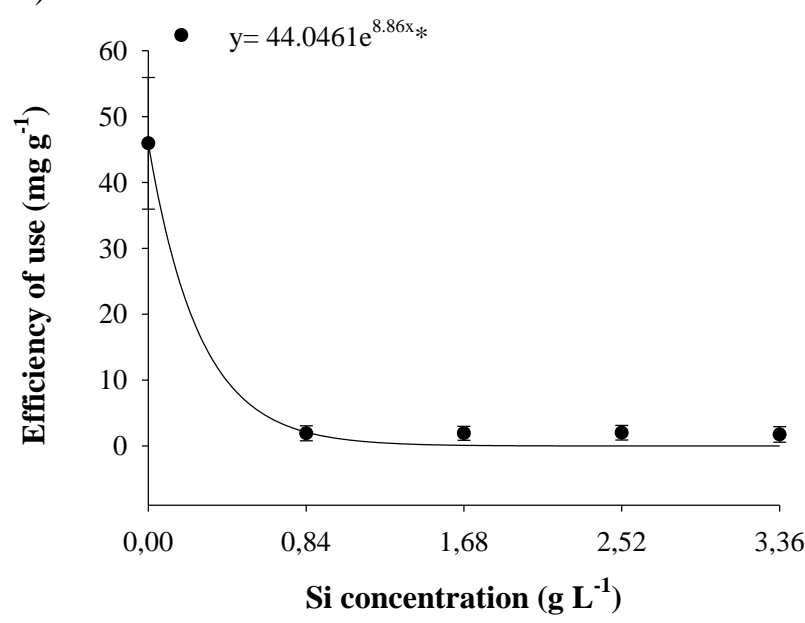

Source: Authors.

Figure 5. Demonstration of the production rice system by economic balance bias in function of Si doses and the maximum yield according nutritional requirements.

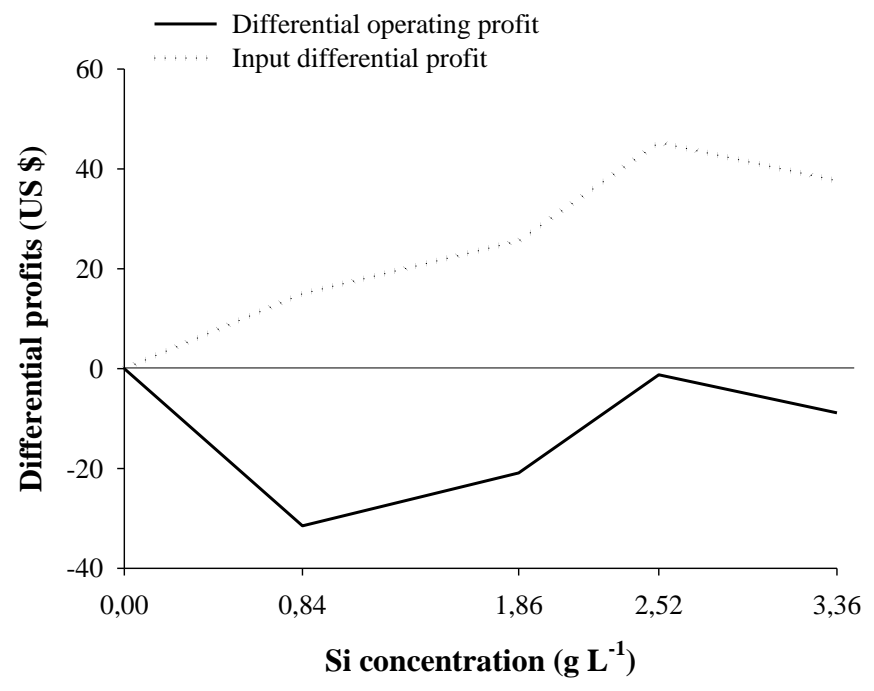

Source: Authors. 


\section{Discussion}

As already reported by several studies silicon can participate in some important metabolic pathways (Sahebi et al., 2015; Frew et al., 2018), with primary metabolism among them (Sahebi et al., 2015), which plays a role in the growth and vegetative development of plants (Zargar et al., 2019). Our study supported some of these shreds of evidence, as the variation of doses affected plant height and leaf area as a function of increasing Si (Figure 1).

The increase in leaf area observed in our study (Figure 1) was supported by Manivannan \& Ahn (2017), who reported to the existence of a gene involved in photosynthesis of species of the Poaceae family under stress when Si was applied. Peixoto et al. (2020) also observed increases in the leaf area of sunflower with foliar silicon application. In this study, we observed that even with increasing leaf area, there were no losses in $\mathrm{CO}_{2}$ assimilation, water status, or $\mathrm{N}$ concentration, which resulted in increased biomass production. These data corroborate with our study, in which stomatal conductance, transpiration rate and, mainly, photosynthetic rate increased along with leaf area, resulting in biomass gain.

Studies show the importance of $\mathrm{Si}$ in the photosynthetic rate of various crops (Flores et al., 2018a; Oliveira et al., 2020b; Teixeira et al., 2020). Normally, when the plant leaf area increases, we expect the foliar N content to be distributed throughout the leaf blade, decreasing production of photosynthetic tissue per $\mathrm{m}^{2}$ of leaf (Peixoto et al., 2020). During photosynthesis, the enzyme rubisco (1,5 ribulose bisphosphate carboxylase/oxygenate) is the most limiting, with increased $\mathrm{N}$ cost for leaf construction, compromising between 20-30\% of all foliar N (Busch \& Sage, 2017).

Although we have not evaluated foliar $\mathrm{N}$ content in the present study, we believe that $\mathrm{N}$ assimilation by the plant increased even with increasing leaf area, as photosynthesis rates increased due to the increase in plant Si content. Xie et al. (2014) and Bueno et al. (2017) observed increases in total chlorophyll contents as a function of Si supply to the plants, suggesting increased $\mathrm{N}$ assimilation by plants, as reported by Peixoto et al. (2020). Some studies have shown direct correlation between increases of Si and chlorophyll a contents in the plant (Zanetti et al., 2016) and chlorophyll a production over time (Hoppe et al., 2013). In addition, the results of the present study raise the hypothesis that increased accumulation of Si in millet (Figure 3) may stimulate production of chlorophyll a throughout plant development, which would occur due to the physiological longevity of millet, as reported for other plant groups (Chen et al., 2011; Zanetti et al., 2016; Haddad et al., 2018).

Still referring to data found by Xie et al. (2014), stomatal conductance and transpiration increased as the silicon supply quantitatively increased. We have also found similar results, although millet showed a response limit of up to $2.52 \mathrm{~g} \mathrm{~L} \mathrm{~L}^{-1} \mathrm{of}$ applied to leaves, suggesting that this crop has response restrictions for application of higher concentrations. We highlight that some plants under biotic and abiotic stress develop mechanisms for survival, and these results demonstrated that stomatal conductance and transpiration were efficient as stress indicators for millet (Figure 2). Stress in physiological parameters after Si application has also been reported by other studies (Currie \& Perry, 2007).

Still regarding shoot development, studies performed with other plant groups also showed increased plant height, such as for rice (Zanetti et al., 2016; Couto et al., 2020), passion fruit (Costa et al., 2016), potato (Soratto et al., 2019), peanut (Dong et al., 2018), sunflower (Flores et al., 2018b), and tomatoes when not subjected to water stress (Moraes et al., 2020). Therefore, evidence demonstrates that for this parameter Si is highly responsive, and can be an alternative resource for plant development, especially for foliar application, as evidenced by the present study.

We note that foliar silicon application favored its uptake and accumulation in the millet plant (Figure 3), which was also evidenced by the increased efficiency of Si uptake and transport in the plant (Figure 4). As reported by other studies, by stimulating photosynthesis, the hypothesis that $\mathrm{Si}$ accumulates in leaves was raised and confirmed by studies that used imaging technique and proved that Si tends to accumulate in leaves (Guerriero et al., 2020), as reinforced in our study. As already reported (Epstein, 2009) the millet crop is considered Si-accumulating, and we proved this behavior as Si concentrations in the plant exceeded $10 \mathrm{~g} \mathrm{~kg}^{-1}$ at the dose of $0.84 \mathrm{~g} \mathrm{~L}^{-1}$ of Si (Figure 3). 
We highlight that in other crops of the Poeceae family, such as rice (Couto et al., 2020), sugarcane (Teixeira et al., 2020), maize (Oliveira et al., 2020a), sorghum (Flores et al., 2018a; Oliveira et al., 2019; Oliveira et al., 2020a), and wheat (Qamar et al., 2020), foliar supply of soluble Si sources has been shown to be efficient to increase the uptake and accumulation of the beneficial element. Si usually has low mobility in the phloem, being considered little mobile in plants (John \& Raven, 1983; Raven, 2001; Malavolta, 2006), suggesting the need for studies on highly soluble Si sources for supply to crops.

$\mathrm{Si}$ increase in the millet plant can be explained by the source that we used in the present study, as Flores et al. (2018a) attributed this behavior to the presence of the syrup stabilizer sorbitol (simple sugar with low molecular weight), which is capable of promoting solubility of $\mathrm{Si}$ in the membrane and slightly increase the mobility of $\mathrm{Si}$ in the phloem. Such behavior would explain $\mathrm{Si}$ increase in the roots, as was subtly demonstrated by the present study. There are reports in the literature of deposition of large Si concentrations in the leaf blade (Silva et al., 2015; Zanetti et al., 2016; Flores et al., 2018a), and in the case of millet, it may also be another explanation for the increasing responses to $\mathrm{Si}$ application.

As the physiological quality of millet plants improved, as observed in Figure 2, dry biomass production also improved (Figure 1). This behavior was also observed in other studies, such as for sorghum (Flores et al., 2018a), rice (Couto et al., 2020), industrial processing tomato (Moraes et al., 2020), and sunflower (Flores et al., 2018b; Peixoto et al., 2020), both studies with foliar silicon application.

Correlation between Si uptake and transport efficiency and dry matter production of grasses is known (Motomura et al., 2002), which was also observed in the present study, with a beneficial effect of Si for leaf area and shoot height and dry matter production. Other studies have also observed increases in Si uptake and transport efficiency, such as for sorghum (Flores et al., 2018a), sunflower (Flores et al., 2018b), and rice, which had a maximum dose close to the concentration of $2.52 \mathrm{~g} \mathrm{~L}^{-1}$ of Si, suggesting it as the maximum saturation of Si utilization by the plant.

When we performed economic analysis in relation to $\mathrm{Si}$ application for the millet crop, we observed that when analyzing only the differential profits of input there are gains only up to the cost of input, US $\$ 45.32 \mathrm{ha}^{-1}$ with the use of $2.52 \mathrm{~g} \mathrm{~L}^{-1}$ of Si in spray volume of $100 \mathrm{~L} \mathrm{ha}^{-1}$. However, when we include the operational costs of application, profits are negative. Thus, we highlight the possibility of applying potassium and sodium silicate associated with pesticides or other fertilizers, which should be performed carefully regarding syrup $\mathrm{pH}$ as to avoid Si precipitation and, consequently, decreased application efficiency. Oliveira et al. (2020b) demonstrated that it is possible to apply potassium silicate associated with $\mathrm{Mn}$ in the form of chelates (Mn-EDTA 13\%) with stabilizers sorbitol, fulvic acid, and salicylic acid, both for maize and sorghum crops. Guedes et al. (2020) and Prado et al. (2020) also observed the possibility of applying potassium and sodium silicate as Si sources along with $\mathrm{Zn}$ in the form of chelates (Zn-EDTA 14\%) with stabilizers sorbitol, fulvic acid, and salicylic acid in the sorghum crop. Therefore, we highlight that the $\mathrm{Si}$ source used in the present study can be associated with other foliar fertilizers, which can reduce the operational costs of application and enable economic gains with $\mathrm{Si}$ application to the millet crop.

\section{Conclusion}

Foliar silicon application in the form of sodium silicate and potassium stabilized with sorbitol was efficient to provide the element for the millet crop, increasing Si content and leaf accumulation, stomatal conductance, and the transpiration rate up to the concentration of $2.52 \mathrm{~g} \mathrm{~L}^{-1} \mathrm{de} \mathrm{Si}$.

Millet plants was responsive in terms of dry biomass production over to a dose of $3.36 \mathrm{~g} \mathrm{~L}^{-1}$ of Si, accompanied by gain in net photosynthetic rate and Si uptake and transport efficiency.

Silicon application is economically viable when the operational costs of application are suppressed, reaching US $\$ 45.32$ $\mathrm{ha}^{-1}$ with application of $2.52 \mathrm{~g} \mathrm{~L}^{-1}$ of $\mathrm{Si}$. 


\section{Acknowledgments}

The authors would like to thank the funding provided by the Coordination of Superior Level Staff Improvement (CAPES) and National Council for Science and Technology (CNPq). AFA and AMB would like to thank CAPES for the funds provided from the SD (National Program of Social Demand). RAF would like to thank CNPq for the PQ funds process number 306329/2019-0.

\section{References}

Bueno, A. C. S. O., Castro, G. L. S., Silva Junior, D. D., Pinheiro, H. A., Filippi, M. C. C., \& Silva, G. B. (2017). Response of photosynthesis and chlorophyll a fluorescence in leaf scald-infected rice under influence of rhizobacteria and silicon fertilizer. Plant Pathology, 66(9), 1487-1495. https://doi.o $\mathrm{rg} / 10.1111 / \mathrm{ppa} .12690$

Busch, F. A., \& Sage, R. F. (2017). The sensitivity of photosynthesis to $\mathrm{O}_{2}$ and $\mathrm{CO}_{2}$ concentration identifies strong Rubisco control above the thermal optimum. New Phytologist, 213(3), 1036-1051. https://doi.org/10.1111/nph.14258

Chen, W., Yao, X., Cai, K., \& Chen, J. (2011). Silicon alleviates drought stress of rice plants by improving plant water status, photosynthesis and mineral nutrient absorption. Biological Trace Element Research, 142(1), 67-76. https://doi.org/10.1007/s12011-010-8742-x

Costa, B. N. S., Dias, G. D. M. G., Costa, I. D. J. S., De Assis, F. A., Da Silveira, F. A., \& Pasqual, M. (2016). Silício no crescimento e estabilidade genética de plantas de maracujazeiro. Acta Scientiarum - Agronomy, 38(4), 503-511. https://doi.org/10.4025/actasciagron.v38i4.30939

Couto, C. A., Flores, R. A., Neto, J. C., Peixoto, M. de M., Souza Junior, J. P., Prado, R. de M., Mesquita, M., \& Damin, V. (2020). Crescimento, biomassa e qualidade fisiológica do arroz em função da aplicação foliarde silício. Brazilian Journal of Development, 6(4), 18997-19014. https://doi.org/10.34117/bjdv6n4170

Currie, H. A., \& Perry, C. C. (2007). Silica in plants: Biological, biochemical and chemical studies. Annals of Botany, 100(7), 1383-1389. https://doi.org/10.1093/aob/mcm247

Dong, Z., Li, Y., Xiao, X., Chen, Y., \& Shen, X. (2018). Silicon effect on growth, nutrient uptake, and yield of peanut (Arachis hypogaea L.) under aluminum stress. Journal of Plant Nutrition, 41(15), 2001-2008. https://doi.org/10.1080/01904167.2018.1485163

Epstein, E. (2009). Silicon: its manifold roles in plants. Annals of Applied Biology, 155(2), 155-160. https://doi.org/10.1111/j.1744-7348.2009.00343.x

Flores, R. A., Arruda, E. M., Damin, V., Junior, J. P. S., Maranhão, D. D. C., Correia, M. A. R., \& Prado, R. de M. (2018a). Physiological quality and dry mass production of Sorghum bicolor following silicon (Si) foliar application. Australian Journal of Crop Science, 12(4), 631-638. https://doi.org/10.21475/ajcs.18.12.04.pne967

Flores, R. A., Arruda, E. M., Souza Junior, J. P. de, de Mello Prado, R., Santos, A. C. A. dos, Aragão, A. S., Pedreira, N. G., \& da Costa, C. F. (2018b). Nutrition and production of Helianthus annuus in a function of application of leaf silicon. Journal of Plant Nutrition, 42(2), 137-144. https://doi.org/10.1080/01904167.2018.1549678

Frew, A., Weston, L. A., Reynolds, O. L., \& Gurr, G. M. (2018). The role of silicon in plant biology: A paradigm shift in research approach. Annals of Botany, 121(7), 1265-1273. https://doi.org/10.1093/aob/mcy009

Guerriero, G., Stokes, I., Valle, N., Hausman, J., \& Exley, C. (2020). Sculptures and Elemental Imaging. Cells, 9(1066), 1-19.

Gupta, S. K., Patil, K. S., Rathore, A., Yadav, D. V., Sharma, L. D., Mungra, K. D., Patil, H. T., Gupta, S. K., Kumar, R., Chaudhary, V., Das, R. R., Kumar, A., Singh, V., Srivastava, R. K., Gupta, R., Boratkar, M., Varshney, R. K., Rai, K. N., \& Yadav, O. P. (2020). Identification of heterotic groups in South-Asianbred hybrid parents of pearl millet. Theoretical and Applied Genetics, 133(3), 873-888. https://doi.org/10.1007/s00122-019-03512-z

Haddad, C., Arkoun, M., Jamois, F., Schwarzenberg, A., Yvin, J. C., Etienne, P., \& Laîné, P. (2018). Silicon promotes growth of Brassica napus L. And delays leaf senescence induced by nitrogen starvation. Frontiers in Plant Science, 9(April), 1-13. https://doi.org/10.3389/fpls.2018.00516

Hoppe, H. G., Giesenhagen, H. C., Koppe, R., Hansen, H. P., \& Gocke, K. (2013). Impact of change in climate and policy from 1988 to 2007 on environmental and microbial variables at the time series station Boknis Eck, Baltic Sea. Biogeosciences, 10(7), 4529-4546. https://doi.org/10.5194/bg-10-4529-2013

Jukanti, A. K., Gowda, C. L. L., Rai, K. N., Manga, V. K., \& Bhatt, R. K. (2016). Crops that feed the world 11. Pearl Millet (Pennisetum glaucum L.): an important source of food security, nutrition and health in the arid and semi-arid tropics. Food Security, 8(2), 307-329. https://doi.org/10.1007/s12571-016-0557y

Korndörfer, G. H., Pereira, H. S., \& Nolla, A. (2004). Análise de silício: solo, planta e fertilizante. UFU, Uberlândia.

Lanna, A., Mitsuzono, S., Terra, T., Pereira Vianello, R., \& Carvalho, M. (2016). Physiological characterization of common bean ("Phaseolus vulgaris" L.) genotypes, water-stress induced with contrasting response towards drought. Australian Journal of Crop Science, 10(1), 1-6.

Li, Y., Hagen, G., \& Guilfoyle, T. J. (1991) An auxin-responsive promoter is differentially induced by auxin gradients during tropisms. Plant Cell, 3, 11671175. https://doi.org/10.1105/tpc.3.11.1167

Malavolta, E. (Eurípedes). (2006). Manual de nutrição mineral de plantas. Agronomica Ceres. 
Manivannan, A., \& Ahn, Y. K. (2017). Silicon regulates potential genes involved in major physiological processes in plants to combat stress. Frontiers in Plant Science, 8(August), 1-13. https://doi.org/10.3389/fpls.2017.01346

Moraes, D. H. M. de, Mesquita, M., Flores, A. M. B. R. A., Oliveira, H. F. E. de, Lima, F. S. R. de, Prado, R. de M., \& Battisti, R. (2020). Combined Effects of Induced Water Deficit and Foliar Application of Silicon on the Gas Exchange of Tomatoes for Processing. Agronomy, 10(11), 1715. https://doi.org/10.3390/agronomy 10111715

Motomura, H., Mita, N., \& Suzuki, M. (2002). Silica accumulation in long-lived leaves of Sasa veitchii (Carrière) rehder (Poaceae-Bambusoideae). Annals of Botany, 90(1), 149-152. https://doi.org/10.1093/aob/mcf148

Noronha, J. F. (1987). Projetos agropecuários: administração financeira, orçamento e viabilidade econômica (2 th). Atlas.

Oliveira, R. L. L., Prado, R. M., Felisberto, G., \& Cruz, F. J. R. (2019). Different Sources of Silicon by Foliar Spraying on the Growth and Gas Exchange in Sorghum. Journal of Soil Science and Plant Nutrition. https://doi.org/10.1007/s42729-019-00092-1

Oliveira, K. S., de Mello Prado, R., \& de Farias Guedes, V. H. (2020a). Leaf spraying of manganese with silicon addition is agronomically viable for corn and sorghum plants. Journal of Soil Science and Plant Nutrition, 1-9. https://doi.org/10.1007/s42729-020-00173-6

Oliveira, K. S., de Mello Prado, R., \& de Farias Guedes, V. H. (2020b). Leaf Spraying of Manganese with Silicon Addition Is Agronomically Viable for Corn and Sorghum Plants. Journal of Soil Science and Plant Nutrition, 1-9. https://doi.org/10.1007/s42729-020-00173-6

Pati, S., Pal, B., Badole, S., Hazra, G. C., \& Mandal, B. (2016). Effect of Silicon Fertilization on Growth, Yield, and Nutrient Uptake of Rice. Communications in Soil Science and Plant Analysis, 47(3), 284-290. https://doi.org/10.1080/00103624.2015.1122797

Peixoto, M. de M., Flores, R. A., do Couto, C. A., Pacheco, H. D. N., Prado, R. de M., Souza-Junior, J. P., Castro-Netto, J. A., \& Graciano-Ribeiro, D. (2020). Silicon Application Increases Biomass Yield in Sunflower by Improving the Photosynthesizing Leaf Area. Silicon. https://doi.org/10.1007/s12633-020-008182

Pompeu, R. C. F. F., Andrade, I. R. A. de, Martins, E. C., \& Oliveira, H. A. de S. F. G. L. R. G. T. L. S. (2013). Produtivid ade e custos de produção da silagem de sorgo, milheto e girassol cultivados em agricultura de sequeiro para alimentação de ovinos no Semiárido brasileiro. VIII Congresso Nordestino de Produção Anual, 5 .

Prado, V. H. de F. G. R. de M., Frazão, J. J., Oliveira, K. S., \& Cazetta, J. O. (2020). Foliar-Applied Silicon in Sorghum (Sorghum bicolor L.) Alleviate Zinc Deficiency. Silicon. https://doi.org/10.1007/s12633-020-00825-3

Qamar, R., Anjum, I., Atique-ur-Rehman, Safdar, M. E., Javeed, H. M. R., Rehman, A., \& Ramzan, Y. (2020). Mitigating water stress on wheat through foliar application of silicon. Asian Journal of Agriculture and Biology, 8(1), 1-10. https://doi.org/10.35495/ajab.2019.04.174

Raven, J. A. (2001). Chapter 3 Silicon transport at the cell and tissue level. Studies in Plant Science, 8(C), 41-55. https://doi.org/10.1016/S0928-3420(01)80007-

Raven, J. A. (1983). The transport and funcion of silicon in plants. Biological Reviews, 58(2), 179-207. https://doi.org/10.1111/j.1469-185x.1983.tb00385.x

Román, R. A. A., Cortez, J. W., Oliveira, J. R. G. di, \& Ferreira, M. da C. (2019). Pulverização de fungicida na cultura da soja em função de ponta e volumes de aplicação. Parte 1: Avaliação de cobertura. IV Sintag - Simpósio Internacional de Tecnologia de Aplicação de Agrotoxicos, 4, 25-28.

Sahebi, M., Hanafi, M. M., Siti Nor Akmar, A., Rafii, M. Y., Azizi, P., Tengoua, F. F., Nurul Mayzaitul Azwa, J., \& Shabanimofrad, M. (2015). Importance of silicon and mechanisms of biosilica formation in plants. BioMed Research International, 2015. https://doi.org/10.1155/2015/396010

Silva, E. S., Prado, R. M., Santos, D. M. M., Cruz, F. J. R., \& Campos, C. N. S. (2015). Nitrogen components, growth and gas exchange in spring wheat plants grown under interaction of silicon (Si) and nitrogen (N). Australian Journal of Crop Science, 9(9), 790-798.

Soratto, R. P., Fernandes, A. M., Pilon, C., \& Souza, M. R. (2019). Phosphorus and silicon effects on growth, yield, and phos phorus forms in potato plants. Journal of Plant Nutrition, 42(3), 218-233. https://doi.org/10.1080/01904167.2018.1554072

Sousa, D. M. G. de, \& Lobato, E. (2004). Cerrado: Correction of soil and fertilization. In Embrapa Cerrados (2 th).

Swiader, J. M., Chyan, Y., \& Freiji, F. G. (1994) Genotypic differences in nitrate uptake and utilization efficiency in pumpkin hybrids. Journal of Plant Nutrition, 17, 1687-1699. https://doi.org/10.1080/01904169409364840

Teixeira, G. C. M., de Mello Prado, R., Oliveira, K. S., D’Amico-Damião, V., \& da Silveira Sousa Junior, G. (2020). Silicon Increases Leaf Chlorophyll Content and Iron Nutritional Efficiency and Reduces Iron Deficiency in Sorghum Plants. Journal of Soil Science and Plant Nutrition. https://doi.org/10.1007/s42729020-00214-0

Teixeira, G. C. M., Mello Prado, R., Rocha, A. M. S., Santos, L. C. N., Santos Sarah, M. M., Gratão, P. L., \& Fernandes, C. (2020). Silicon in pre-sprouted sugarcane seedlings mitigates the effects of water deficit after transplanting. Journal of Soil Science and Plant Nutrition, 1-11. https://doi.org/10.1007/s42729019-00170-4

Teixeira, P. C., Donagemma, G. K., Fontana, A., \& Teixeira, W. G. (Eds.). (2017). Manual de métodos de análise de solo (3 th). Embrapa.

Xie, Z., Song, F., Xu, H., Shao, H., \& Song, R. (2014). Effects of silicon on photosynthetic characteristics of maize (Zea mays L.) on alluvial soil. Scientific World Journal, 2014. https://doi.org/10.1155/2014/718716

Zanetti, L. V., Milanez, C. R. D., Gama, V. N., Aguilar, M. A. G., Souza, C. A. S., Campostrini, E., Ferraz, T. M., \& Figueiredo, F. A. M. M. A. (2016). Leaf application of silicon in young cacao plants subjected to water deficit. Pesquisa Agropecuária Brasileira, 51(3), $215-223$. 
Research, Society and Development, v. 10, n. 4, e41610414232, 2021

(CC BY 4.0) | ISSN 2525-3409 | DOI: http://dx.doi.org/10.33448/rsd-v10i4.14232

Zargar, S. M., Mahajan, R., Bhat, J. A., Nazir, M., \& Deshmukh, R. (2019). Role of silicon in plant stress tolerance: opportunities to achieve a sustainable cropping system. 3 Biotech, 9(3), 0. https://doi.org/10.1007/s13205-019-1613-z 